\title{
Renal Interstitial Tissue
}

National Cancer Institute

\section{Source}

National Cancer Institute. Renal Interstitial Tissue. NCI Thesaurus. Code C33459.

Renal tissue consisting of peritubular and periarterial spaces. The relative contribution of each of these two spaces to interstitial volume varies, but increases in size from the cortex to the papilla. In the cortex there is little interstitium because the peritubular capillaries occupy most of the space between the tubules. The cortical interstitial cells and outer medula consist mainly of fibroblastic cells and mononuclear cells. The inner medulla consists primarily of pericytes, lipid-laden cells and mononuclear cells arranged like rungs of a ladder. 